\title{
口腔内補綴物に対する造影法の検討
}

増田元三郎・古賀一郎・深谷忠芳 - 村瀬博文

増田正樹・大谷隆俊・福田広志*

\section{Radiography of oral prostheses with a new type of contrast media}

\begin{abstract}
Genzaburo Masuda - Ichiro Koga - Tadayoshi Fukagar - Hirofumi Murase Masaki MASUdA - Takatoshi OHTANI - Hiroshi FukUdA*
\end{abstract}

緒

\section{言}

口腔外科領域疾患のうち，顎骨腫瘍，奇形，外傷など では一般飞，外科的処置が行われている、特顸䫑骨腫湯 摘出後では，しばしば発音，咀獣機能等の障害がみられ る。

当科では，過去 12 年間，上顎腫瘍の根治的外科手術後

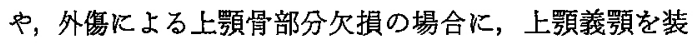
着し，機能改善に努めてきた 一部症例に対しては，スピーチェイドを用いて言語治療 を行ってきだ).

これらの口腔内補綴物を装着する際に，口腔機能に最 も影響を及济するのは，補綴物の維持と周囲組織との適 合性であると考える.

上䫑義靧の場合には，周囲組織とどのような位置的関 係沈るとき維持が良く，十分に機能を発揮できるかが 大きな問題である，たと充は，義顓の栓塞子部では，根

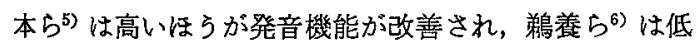
いほらが良いと述べ，かならずしも一致した見解はない ようである。

一方, スピーチェイドの場合には、バルブと上咽頭壁と の位固的関係が機能に大きな影響を及ぼす。これらの閣 題を解決するために従来から間接的飞軟口蓋造影法7)な どが試みられているが，口腔内補経物の位置を確認する

横浜市立大学医学部口腔外科学教室 (主任：大谷 隆陖教授)

* 東京医科菌科大学齿学部蒾科麻醉学教室（主任： 久保田雪耶教授)

Department of Oral Surgery, School of Medicine, Yokohama City University (Chief: Prof. Takatoshi Ohtani)

* Department of Anesthesiology, School of Dentistry, Tokyo Medical and Dental University (Chief: Prof. Yasuya Kubota)

受付日：昭和54年 1 月 16 日
ために直接的造影法の検討は忹とんど行われていない． 今回, われわれは, 口腔内補緅物飞造影剤を塗布乙周 囲組織との関係を明らかにしようと試みた。

\section{材料および方法}

造影剤としては，消化管造影剤に用いられている硫酸 パリウム $100 \mathrm{~g}$ をイドロキシプロピルセルロース（以 下 HPC と略す) の $2 \%$ 溶液 $100 \mathrm{~m} l$ に溶いた溶液を用 いた。

\section{方 法}

1)パリウム HPC を筆にてロ腔内補緅物にうすく均 一飞塗布する。

2)バリウム HPC を乾燥させる.

3）同補緅物表面をテトラメチルチウラムジスルフィ ドを配合した $\beta$-ェトキシェチルメタフクリル樹脂（， ベクタン) スプレーで貲霧しアクリル被膜のコーティン グを行ら (写真 1 ).

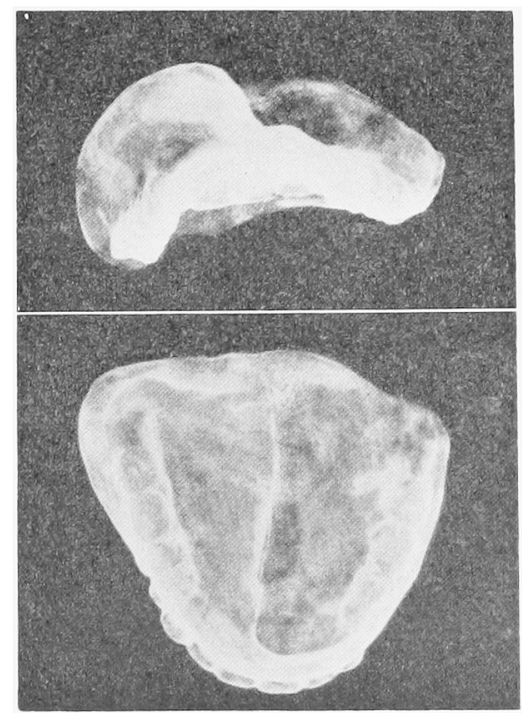

写真 1 造影剤塗布後の義顎のX線写真 


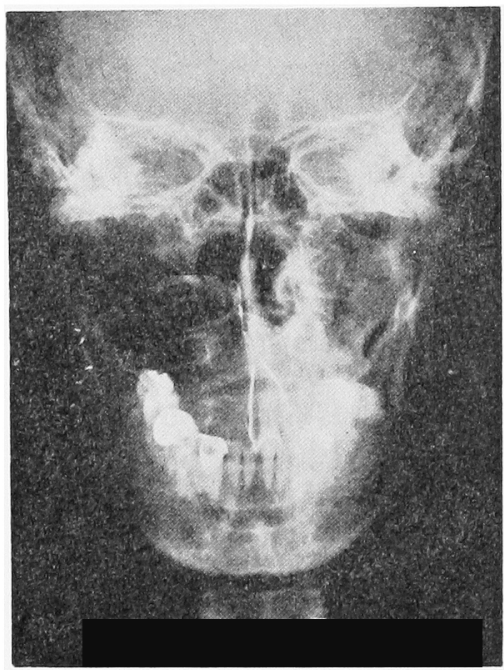

写真 2 症例 $1: \mathrm{P} \rightarrow \mathrm{A}$ 像

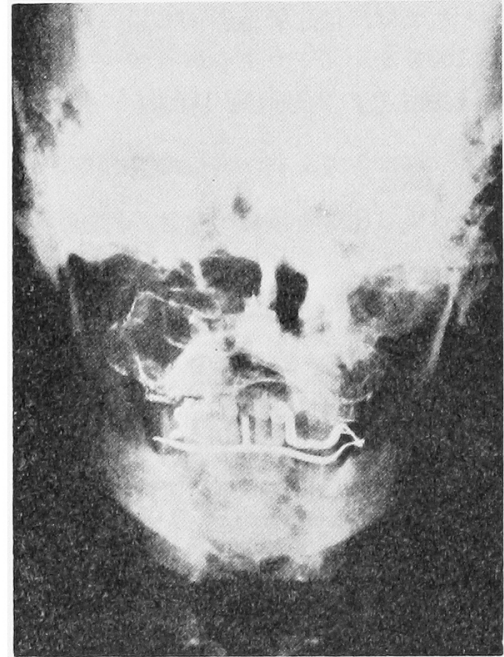

写真 3 症例 $2: \mathrm{P} \rightarrow \mathrm{A}$ 像

このようにハシリウム $\mathrm{HPC}$ 溶液塗布後, ノべクタンス プレールてコーティングした口腔内補経物を通常ど物り 患者に装着させX線撮影を行った。

結果

上顎義顎に関しては，顔面後前方向X線写真では，切 除部に插入された上㖽義䫕の周围の形態が（写真 2,3）, 側面方向X線写真では，上頻義顥の後縁の位置と軟口蓋 との関係が明らがなった（写真 4，5）。

スピーチェイドのパルブについては，バルブの形態拉 よび，ハルブと㸶頭壁との関係が明らかになった（写真 6). また顿口蓋造影を併用するとバルブと軟口蓋との関

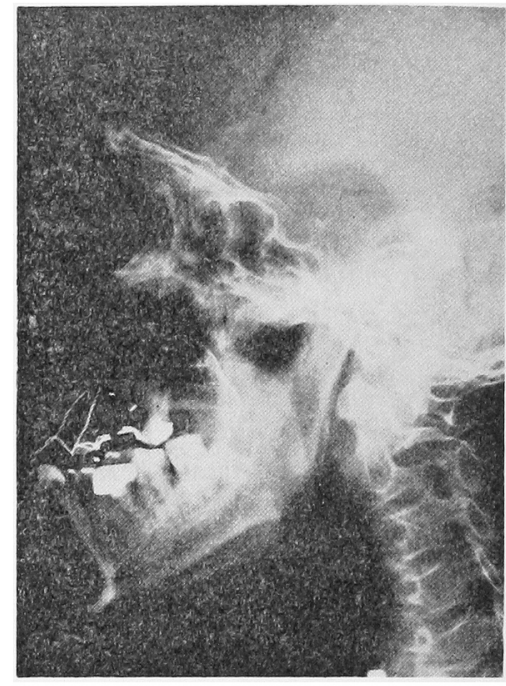

写真 4 症例 $1:$ 側面像

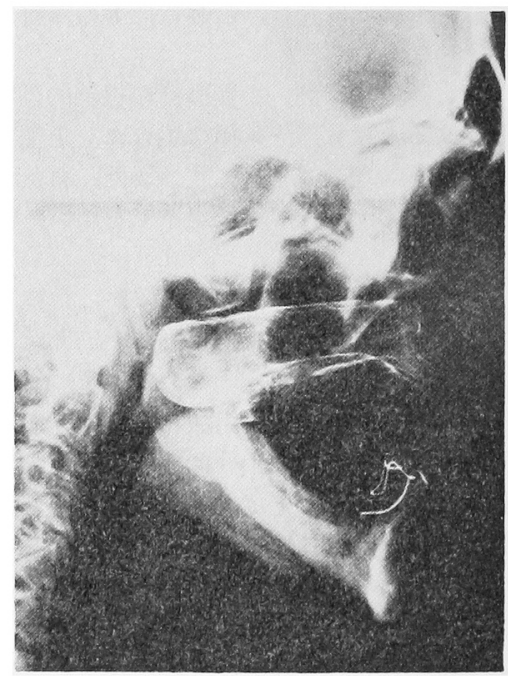

写直 5 症例 $2:$ 側面像

係がざに明らがなった（写真 7).

考察

口腔領域疾患行われている造影法としては，唾液腺 造影法, 副奥腔造影法, 西胞腔造影法, 軟口蓋造影法7,

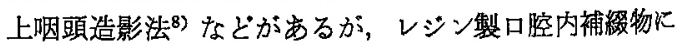
対する造影法の報告は注とんどない，わずかに，スピー チェイドのパルブの位置に関する検討として，岡らはウ ロダラフィンを佘布する方法"，村瀬はアマルガムを混 入する方法すなどがある（写真 8). しかし，ウログラフ 1ンは周囲組䋐へ流出付着し，フマルガムはX線摄影後 アマルガムを除去できないなどの欠点があり，口腽内補 


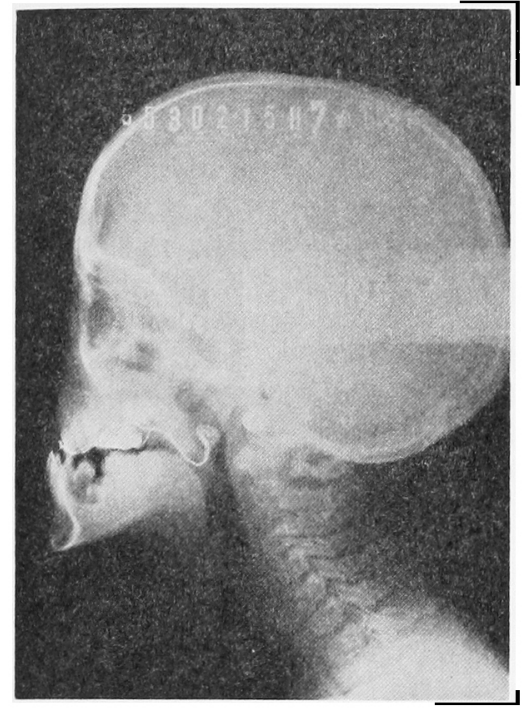

写真 6 スピーチェイド・バルブに造影剤を叙 布したX線規格写真像

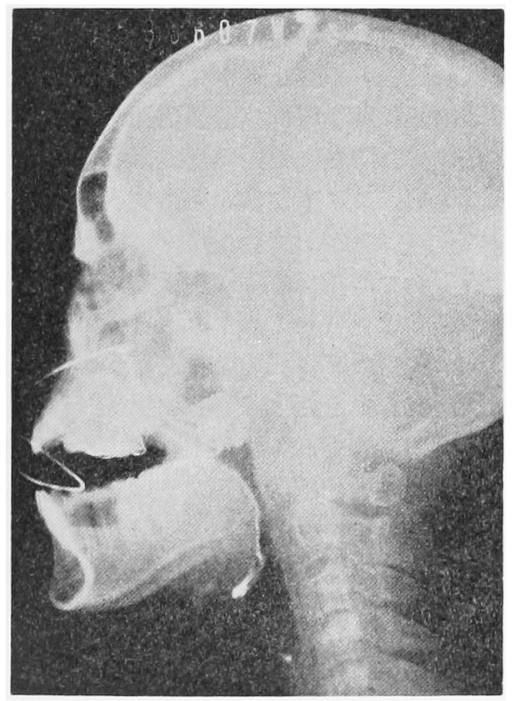

写真 7 軟口蓋造影を併用したX線䙺格写真像

笅物全般に応用できる造影剂はなかった。

われわれは，口腔内補緅物に塗布する造影剂の条件と して,

(1)人体に対し為害性がない

(2) レジンに付着し，均一にちすく塗れる.

(3) 容易に乾燥し，周囲組織へ流れない。

(4) 周囲組織とコントラストの良い像が得られる.

(5) 造影昘の塗布，除去が容易である.

等であると考皇た。

これらの条件に対して、ュージノールセメント，ウ口

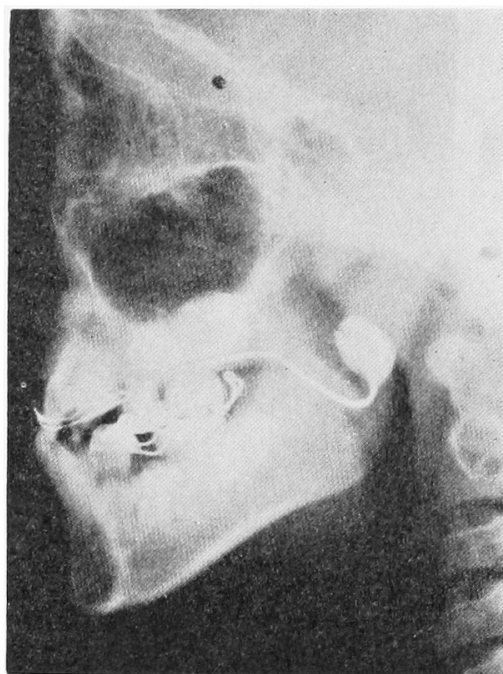

写直 8 スビーチェイド・バルブにママルガム を混入した症例

グラフィン，リピオドール，バリウム水溶液等を染布し て比較検討を行ったが，ュージノールセメントは，レシ ンに対し良好な付着状態を示したが，X線写真上でのコ ントラストが悪く，ウログラフィン等の水溶性造影剂は レシンに付着しなかった.リピオドール等の油性造影剂 はレジン表面に均一に付着はしたが，塗布後，乾燥せず 周团へ造影剂が流れてしまった.パリム水溶液は、レジ ン表面になじまず，はじけてしまい均一に染布できなか ったがX線写真上では良好なコントラストが得られた。

そこでわれわれは，X線写真上で良好なコントラストを 得られたバリウム造影剂の溶媒にレジンとの結合剤とし て $2 \%$ HPCを用いた. HPCを $2 \%$ とたのは，そ れ以下では結合剤として十分な機能を発揮せず，また， $2 \%$ 以上ではパリウムを溶く際，気泡が発生しやすいた めである，2\% HPC に溶かされたバリウム造影剂は， 適度な粘度をもち、レジル均一に薄く付着した。

HPC は本来, 食品添加物として利用されて拈り安全 性は確認されている10) ノベクタンは殺菌性包帯剤とし て用いられて敊り，われわれは，同剂にて，バウム HPC 層を被い，造影剂の周囲への流出和よび補緅物装着時の 摩擦による造影剂の剩離を防いだ，バリウム $\mathrm{HPC}+ア$ クリル被膜を除去する際には，酒精綿花にて擦拭するこ とで容易に除去できる。

造影X線写真上で，口腔内補緅物と軟組織との適合を 見る祭に，スピーチェイドのバルブのよらに形態の単純 なものは判読しやすいが，義顠のように形態の複雑なる のは造影像が重なり合い判読しにくい：しかし正面方 向，側面方向なと，多方向のX線写真撮影により，義顎 と周囲組織との位置的な概念は把握できる。しかしなが ら，本法が，口腔内補緅物の適合性について，どの度 
有用であるかは不明である，本法に加えて，周囲の軟組 織造影を併用し，かつX線撮影条件，方向などを工夫す ることにより適合性についてある程度の知見は得られる と考える. 今後, これらの点についてさらに検討を加え る予定である。

\section{結語}

われわれは，口腔外科疾患の際に装着する口腔内補綴 物と周囲組織との関係を明らかにするため，口腔内補経 物造影法を考案した。

造影剂として，硫酸バリウム $100 \mathrm{~g}$ を $2 \%$ HPC 100 $\mathrm{m} l$ に溶いた溶液を用いた。それを口腔内補経物に薄く 均一に塗布し, 通常どおり装着させX線撮影を行った。

造影X線写真上で，スピーチェイドのバルブのように 比較的形態の単純なるのは, 周囲組織との関係は明瞭と なったが，上䪽義顎のように形態の複雑なるのは，造影 像が重なり合い, 判読しにくい. しかし，X線撮影方法 の検討, 周用の軟組織造影法との併用により補緅物の位 㯰的な概念は把握できると考える。

本論文の要旨は, 第 1 回顎顔面補緅研究会総会（昭和 53年 5 月 20 日), 第 111 回日本口腔外科学会関東地方会 （昭和53年 6 月24日）において発表した。

\section{引用文 献}

1) 增田正樹, 他：䝷骨尰湯摘出後のオーラル・リ
ハビリテーションの研究 第 1 報磁力を応用 した上顎部顎補経。口科誌 22：261973.

2) 增田正樹, 他 : 顎骨腫演摘出後のオーラル・リ ハビリテーションの研究 第 2 報 口腔機能に ついて。只科誌 27: 2721978.

3）福田広志, 他：フェライト系磁石を応用した上 顎義顎の経験。顎顔面補経 1: 331978.

4）村瀬博文：口蓋裂患者の言語治療におけるスピ 一チェイドの臨床的効果に関する研究，日口外 誌 21: 591975.

5）根本一男, 他: 上顎腫瘍摘出患者の補緅 処置 例. 歯界展望 38：606 1971.

6）鵜着 弘，他：硬口蓋欠損に対する栓塞子に関 する臨床実験。補経誌 2：214 1958.

7) 吉田 広：軟口蓋造影 X線規格写真撮影法によ る鼻咽腔諸組織の形態ならびに機能に関する研 究 第 1 報 軟口葢造影 X線規格写真撮影法飞 ついて。病誌 41: 11974.

8）北原哲，他：タンタラム粉末による上咽頭造 影の試み。耳喉 44:57 1972.

9）岡伸光, 他: Speech aid の設計ならびに作 製に関する試験的考案(1). 日口外誌 18：172 1972.

10) Kitagawa, H., et al.: Acute toxicities of hydroxypropyl cellulose in mice and rats. 応用 薬理 4: 10131970 . 